\title{
Apiarists' Awareness and Responses to Honey Bee Colony Parasite and Pathogen Infections in Kenya
}

\author{
Onyango Irene Awino ${ }^{1,}$, , Shadrack Muya ${ }^{2}$, Samuel Kabochi ${ }^{1}$, Hellen Kutima ${ }^{2}$, Muo Kasina ${ }^{3}$ \\ ${ }^{1}$ Department of Livestock, Directorate of Veterinary Services, Kabete Veterinary Laboratories, Nairobi, Kenya \\ ${ }^{2}$ Zoology Department, School of Biological Sciences, Jomo Kenyatta University of Agriculture and Technology, Nairobi, Kenya \\ ${ }^{3}$ National Sericulture Research Centre, Kenya Agricultural and Livestock Research Organization, Thika, Kenya
}

Email address:

ironya2000@yahoo.com(O. I. Awino)

${ }^{*}$ Corresponding author

\section{To cite this article:}

Onyango Irene Awino, Shadrack Muya, Samuel Kabochi, Hellen Kutima, Muo Kasina. Apiarists' Awareness and Responses to Honey Bee Colony Parasite and Pathogen Infections in Kenya. International Journal of Natural Resource Ecology and Management.

Vol. 3, No. 4, 2018, pp. 46-52. doi: 10.11648/j.ijnrem.20180304.11

Received: July 20, 2018; Accepted: August 9, 2018; Published: September 6, 2018

\begin{abstract}
Globally, honey bee (Apis mellifera L.) is the most domesticated bee species due to their ability to produce honey of commercial value, wax, pollen, royal jelly and propolis. They also facilitate pollination processes of flowering plants. However, there has been an increase in reported incidences of hive and colony infection by honey bee parasites and pathogens, contributing to colony collapse disorder. This study explored the beekeeper's approaches to hive infestation by bee parasites and pathogens in Kenya. Using a questionnaire, 78 individual beekeepers and 15 beekeeping groups in eleven different Counties in Kenya were surveyed between 2012 and 2013, and their ability to identify and manage honey bee pathogens and parasites was determined. Majority of the farmers (95\%) said they experienced challenges with pests. Ants were the pests mostly mentioned by the apiarists $(90 \%)$, followed by small hive beetles $(32 \%)$, wax moths $(28 \%)$ and pirate wasps $(18 \%)$. Only one respondent mentioned Varroa mites and no respondent mentioned any of the pathogens transmitted by these parasites. Most $(90 \%)$ management practices apiarists mentioned targeted controlling ants. Farmers had no idea of how to control other pest and/or parasites, in spite of their presence as was confirmed by this study that all colonies inspected in all sites were infested with Varroa mites. Majority (93\%) of the apiarist harvested honey at night when visibility is poor and hence could not see other pests and/or pathogens. Apiarist' need education on bee husbandry in order to contain honey bee parasites and pathogens to improve their awareness on the same and to manage colony collapse disorders. They need to embrace colony inspection and honey harvesting during the day when sufficient lighting is available for detection of parasites and pathogens.
\end{abstract}

Keywords: Apis Mellifera, Bee Parasites, Pathogens, Beekeeping Practices

\section{Introduction}

Bees are winged, flower-feeding insects with branched body hairs classified under phylum Arthropoda, class Insecta, and order Hymenoptera [1]. The order constitutes diverse species of bees, wasps, ants, and sawflies. There are seven bee families which are divided into two groups based on labial palpal morphology, the long tongued group and the short-tongued group [2]. Honey bees, Apis mellifera L. belong to the long tongued family Apidae. Ten species of honey bees of the genus Apis have been categorized into three distinct groups. Cavity-nesting bees including $A$. mellifera, A. cerana Fabricius, A. koschevnikovi Enderlein and $A$. nulensis Lin.). Giant bees include $A$. dorsata Fabricius, A. laboriosa Smith and A. nigrocincta Smith). Dwarf bees constitute $A$. florea Fabricius and $A$. andreniformis Smith[3, 4].

Honey bees are social insects living together in large organized family castes consisting of the queen bee, the sterile female worker bee and the male drone [5]. In the bee colony there is division of labor, individuals exchange food and information and the different types of individuals differ 
in ratio and life history schedules [6]. The queen bee is the only reproductive female in the colony, the sterile workers perform all the non-reproductive functions in the colony [7], [5] while the role of male drones is to produce sperms and to mate with the queen [8].

Living socially makes the bees vulnerable to pathogens due to the close and extensive social interactions among individuals. The large homogeneous physical and genetic environment provides for sustainable path for pathogens transmission [9]. The distribution of liquid food by individuals to a large number of other individuals in the colony, otherwise referred to as trophallaxis contributes to the spread of brood diseases [9].

The colony size and density of the host population determines the persistence and transmission of a pathogen in a population as they influence the frequency of interactions among individuals [9]. Larger colonies with bigger workforces have higher contact rate with pathogens outside the colony. Consequently, pathogens would spread faster due to a higher contact rate between infected and non-infected individuals [10].

Beekeeping practices and the beekeepers play a key role in the spread, diagnosis as well as control of new and established diseases [11, 12]. The practice of beekeeping encourages huge colony sizes and densities, as well as interferes with natural selection [13]. Hive arrangement [14], placement of bee colonies in rows and in close proximity to each other, facilitates drifting and increased mites' infestation [15] resulting in parasite virulence, host colony morbidity and death [16]. Crowding of colonies in the apiaries and the use of large modern hives, exposes the bees to an array of pathogens especially where there is established populations of Varroa destructor [17, 18].

Parasites and pathogens stand as a serious threat to the population of bees' worldwide [19]. Declines in bee populations for whichever reason interferes with the role of beekeeping as a source of livelihood. In order to obtain sufficient quantity of honey and hive products, availability of sufficient forage with diverse floral diet, is important for honey bee survival and pathogen resistance [20, 21]. However, ecological degradation of the natural resources [22], change in landscape use through intensive agriculture, and the control of weedy plant species [20, 23], alongside seasonal drought $[24,25]$ have led to the depletion of bee forage. As a result, apiarists' resort to move their colonies from one area to another in search of nectar and pollen sources in order to maintain honey flow [25].

Movement of honey bee colonies in search of forage or for the purpose of trade [26], exposes the colonies to pesticides and pathogens [27]. The interaction of managed or imported bees with wild pollinators, creates a leeway for disease emergence via direct transmission, facilitated by changes in host susceptibility [28]. Weak trade restrictions on imports of honey bee colonies [29] have allowed uncontrolled movement of honey bee swarms by beekeepers for commercial pollination and exploitation of honey-flows [30].

Bees are infected by viruses, protozoans, fungi, bacteria and ectoparasitic mites [31]. Pathogen abundance in individual honey bee colonies is influenced by beekeeping operations, colony health, mite infestation levels, colony genetics, weather, nutrition and agrochemical exposure. The absence of parasites and pathogens in bee colonies guarantees healthy strong bee colonies with high production of honey and other hive products, which is the main purpose of beekeeping. It is vital to ensure high quality of the hive products, however, beekeepers exposes bee colonies to pesticides and hive products to pesticide residues [32, 33] Boecking and Genersch, 2008) through treatment [12]. Antibiotics used in apiculture for the treatment of bacterial infections are similar to those used in veterinary. Relatively high doses are used to treat infections while low doses as applied as growth promoters. There are no Maximum residue limits (MRLs) for bee products hence such antibiotics have direct toxic effect on humans [34]. The presence of chemical residues as well as the existence of the bee pathogens listed by organization of animal health (OIE) affects trade in honey and hive products.

In Kenya, extensive beekeeping is practiced in the arid and semi-arid lands using traditional log hives hanged on trees, covering large areas and away from human and animals habitation. Intensive beekeeping on the other hand, is practiced using modern hives on small to medium scale farms in agriculturally productive parts of the country, inhabited by most people $[35,36]$. Beekeeping as an important alternative source of livelihood for many resource poor farmers, faces a number of setbacks including inefficient technologies, insufficient knowledge, environmental degradation, low production [35] and parasites and pathogens of bees [37].

This paper explores the knowledge of apiarists on the bee parasites and pathogens, their management practices and the possible role they play in their spread through their practices. The beekeeper's approaches to hive infestation by bee parasites and pathogens were assessed in Kenya. Their ability to identify and manage honey bee pathogens and parasites and the practices that could contribute to the spread of bee parasites and pathogens.

\section{Materials and Methods}

Semi-structured questionnaires were administered to 78 individual beekeepers and 15 beekeeping groups. The beekeepers originated from Mwingi, Embu and Kibwezi in Eastern Kenya; Marigat and Narok in Rift Valley; Magarini, Voi and Matuga in the Coast; Ijara in North Eastern; Busia and Siaya in Western Kenya. The interview took place between 2012 and 2013. The variables which were assessed included the apiarist's ability to identify honey bee parasites and pathogens, their management practices to alleviate honey bee parasites and pathogens from honey bee colonies. We also determined presence of parasites (varroa mites) and pathogens in the hives to compare what the apiarists said and the actual situation on the hives. Data was analysed using descriptive statistics. 


\section{Results and Discussions}

\subsection{Type of Bee Hives Owned}

Only three types of bee hives were mentioned to be used in honeybee management as mentioned by the respondents. These included traditional log hives, Langstroth hives and Kenya top bar hives (KTBH). Fifty four of the respondents owned purely traditional hives while 62 of them owned all the three types or two types of the mentioned bee hives. The total number of traditional hives owned by the respondents was 3647 , while modern hives were 1139. Modern hives were mainly owned by the respondents who had practiced beekeeping for an average period of five years and below.

The total number of traditional hives owned $(3,647)$ viz the modern hives owned $(1,139)$ by the respondents in this study, is an indication that more people used traditional beehives than modern hives. Traditional hives were more in areas where beekeeping had been practiced over a long period of time, while in the areas where respondents had practiced beekeeping for a short period, modern hives were the most preferred. The preference to traditional hives was cited by the respondents as due to reluctance to embrace new technology of modern hives. The respondents pointed out that log hives are less to prone to ants' infestation and that they are hardy towards harsh environmental conditions like rains and dry spells. Beekeepers in Marigat, Baringo County had developed 'Turgen' improved log hives, which have two chambers separated by a queen excluder to ensure quality honey and to allow for colony inspection.

\subsection{Honey Production}

The total honey produced during the survey season was 13, $411 \mathrm{~kg}$. Production of honey varied with number of hives owned. The honey was either sold in crude forms $(61 \%)$ or in processed form (39\%). For increased income from beekeeping practice, increased honey production should go hand-in-hand with the quality of the product. Quality may be compromised along the value chain from the colony to the processing point. Honey extracted from combs and apiaries contains pollens, beeswax, and other undesirable materials including yeast. Honey is consequently processed to remove the above mentioned in order to improve its quality and shelf life [38]. Honey processing include filtration and heating by simple straining, thermal heating or water bath and bulking for large quantities [39].

Heat or thermal processing of honey eliminates the microorganisms responsible for spoilage and reduces the moisture content to a level that retards the fermentation process [38]. Contamination of honey and hive products may be initiated by lack of proper hygiene when handling honey [40] through blending or mixing honey from different colonies and locations. It is documented that spores of American foulbrood can be spread through reuse of contaminated beekeeping equipment, feeding of contaminated honey or pollen to colonies, or through the robbing of dead or disease weakened colonies by healthy bees [41]. Field observations showed that beekeepers shared hive equipment like protective gear during harvesting, and they also shared centrifuge or process honey from a common point. Such contaminations are also of consumer health concern, international commercial competition, and better product quality [34].

Beekeepers have collection points for raw honey. At the collection points, the honey is processed using a common centrifuge and packaged for marketing. There lies a risk of transmission of bee brood diseases and sharing the residues load from different colonies and locations. Parasitic mites can also be transported in the honey combs to the processing units. The sharing of such facility is linked to their high costs.

\subsection{Knowledge of Pests and Pathogens in Bee Colonies and Their Management}

Ninety one percent $(n=85)$ of the respondents said they experienced challenges with pests. Ants were the major pest as mentioned by most of the respondents $(90 \%)$. The other pests mentioned included small hive beetles as mentioned by $32 \%$ (27) of the respondents, wax moth, as mentioned by $28 \%(24)$ of the respondents and pirate wasps as mentioned by $18 \%$ (15) respondents (Figure 1). Only one respondent mentioned Varroa mites.

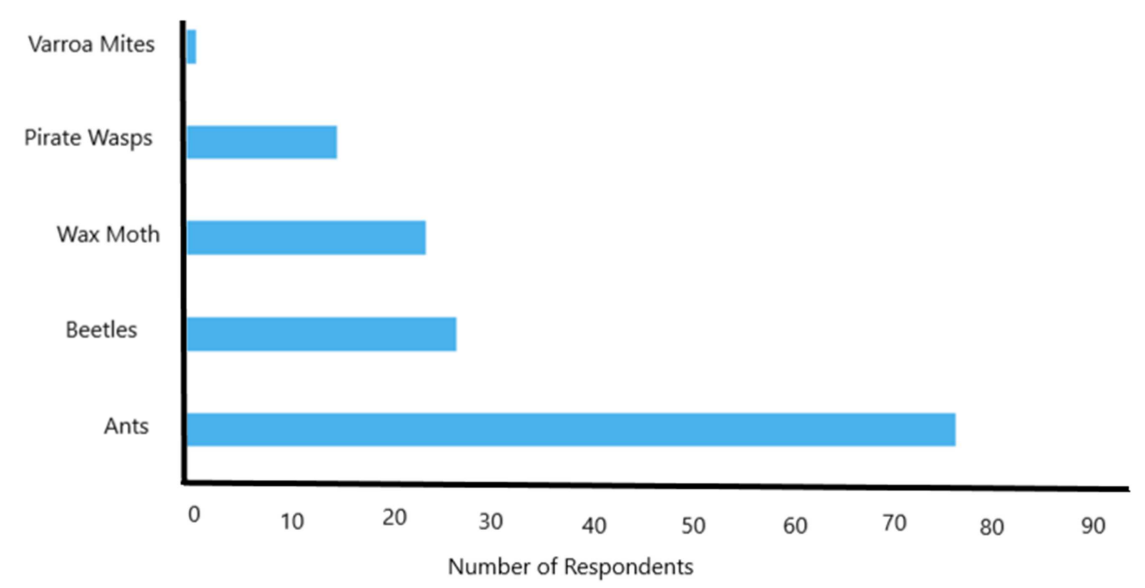

Figure 1. Honey Bee pests observed by beekeepers in their hives in domesticated bee colonies in Kenya in 2012. 
Methods used in controlling these pests as mentioned by the respondents included smoking the hives, greasing the posts of hive stands, use of Sevin dust, ash, and pepper spray and doom to control ants, cleaning hives and hand picking observed pests. Ten of the respondents smoked their hives, 33 respondents applied grease on hive stands, 9 respondents inspected their hives, 18 respondents used Sevin dust, 11 respondents used ash, 7 respondents used pepper spray, 26 six respondents cleaned their hives, 7 respondents' handpicked pests while 3 used doom to kill the ants. The methods of pest management targeted control of ants.

It is apparent that the major pest according to the respondents, were ants. The other important pests were beetles, wax moth and pirate wasps. The beekeepers did not carry out any hive inspection for pests and diseases probably because they were not awareness of their existence. It was also difficult to identify any changes in the colonies or the existence of pests and suspected diseased bees and brood in good time, because they practiced night beekeeping. In this case, hives were only visited at night and when they wanted to harvest honey.

Field colony inspections conducted during the study revealed that wax moth were a major pest in the bee colonies. Smaller and larger hive beetles were also observed in some colonies while Varroa mites were reported in all the colonies inspected in all the different sites.

\subsection{Verification of Presence of Parasites and Pathogens as Acclaimed by Apiarists}

Seventy two hives were opened and inspected. The pests observed were recorded as either present or absent while the numbers of Varroa mites' were recorded per hive. The pests reported included wax moths which was observed through damage caused on the combs, presence of webs and in some cases wax moth larvae. Smaller and larger beetles were observed moving within the colonies and in some cases their larvae were also present. Sugar ants were observed on the hives and their eggs on the hive lids. Of the seventy two hives inspected, 59 were reported to be infested by Varroa mites. The pathogens reported in the colonies inspected included Black queen cell virus, Kakugo virus, Varroa destructor virus-1 as reported in [42]. None of the pathogens were reported by the respondents.

\section{Conclusions}

While reporting the existence of Varroa mites in Kenya in 2009 , it was observed that beekeepers in the country were not aware of the existence of the mite in their colonies, neither had they experienced any negative impact on colony survival or productivity [43]. This paper reveals that the status of beekeepers' knowledge on the existence of the mites has not changed. It was observed that beekeepers did not do any inspection in the hives to check for parasites, pests or diseases; this could be due to lack of knowledge on their existence. The bee colonies were only monitored to time honey harvesting. Harvesting was done at night, making it impossible to identify anything unusual in the colonies. The respondents considered ants as the most important pest in their colonies, and their efforts were focused on the control of the ants, using Sevin dust and others even using doom. The lack of awareness of the pests and parasites could contribute to the continuous spread of the mite in the country through poor beekeeping practices like self-colony multiplication and sharing of hive equipment.

Of the pests of honey bees listed by the world organization of animal health as trade sensitive, only small hive beetle ( 27 respondents) and Varroa mites (1 respondent) were mentioned by the respondent. Only one respondent mentioned Varroa mite, yet all the colonies were infested by the mites although at varying rates. Varroa mites have been reported to be throughout the country $[42,44]$. This is a pointer that, beekeepers need information on the identification of pests and diseases that infect bees and how they are related to hive production, trade in hive products and food production.

Varroa mites' economic threshold is dependent on the proximity of one colony to another. In case of many colonies within 3 - 5 miles of each other, the threshold is lower because of robbing and drifting of bees among colonies hence horizontal transmission [45]. In managed apiaries, honey bee colonies are placed in rows and in close proximity to each other facilitating drifting and increase in mites' infestation $[15,16]$. This was the case in the field observations in this studies. This is a factor that would be contributing to the wide spread of Varroa mites in domesticated honey bee colonies in the country.

Drifting has been reported to play a major role in the transmission of bee parasites and pathogens. Infected drifters may infect other honey bees which they come in contact with. Honey bee drifting may be induced by high colony densities in the apiary, inter-colony distance, distance from windbreaks, presence of landmarks, direction of colony entrance, topography, similarity in hive design and color [14]. To reduce drifting, beekeepers have resorted to space hives and use different hive entrance colors [46]. Spacing of hives only applies to areas where traditional hives are used in the country. However, where modern hives are used hives are placed in close proximity in the apiaries.

Beekeepers are at the core of bee health and should be encouraged to carry out regular hive inspections, to reduce disease incidences and the possible introduction and spread of bee pathogens. Siting of apiaries where bees are exposed to agrochemicals increases their susceptibility to biological infections $[47,48]$. They need to embrace good beekeeping practices which also contribute to reduced spread of bee pathogens. The recent rampant spread of AFB in South Africa has been connected to poor beekeeping practices [49]. Higher colony losses have been observed in migratory beekeeping practices compared to stationery beekeeping practices [49]. Therefore, it is crucial to have a collective understanding of honey bee health through national 
collaboration and establishment of common protocols and promotion of beekeeper knowledge and beekeeping management practices [50]. Beekeepers' knowledge of bee health would provide an avenue for timely management and possible control of bee diseases and ensure adherence to honey safety assurance systems [51]. The importance of compliance with good beekeeping practices based on indepth training in beekeeping and regular monitoring of colonies to maintain the health of apiaries cannot be underscored [52]. Apiarists needed to embrace hygiene to safeguard the quality of their hive product. Quality standards greatly affects trade in such products.

Monitoring for pests and diseases in honey bee was not a common practice in the country. The beekeepers who have been in the practice for more years, have knowledge on honey timing and the important bee forage. The main support that beekeepers received was training on hive management and non on importance of pests and diseases on hive production. The respondents did not know the pests and diseases which affected trade, instead they mentioned black sugar ants. Some respondents used Sevin dust while others used grease to control the ants. In the country from PCPB reports, there are no listed products for control in apiculture. The respondents, who had been in beekeeping practice for long, maintained the use of traditional log hives. These respondents cited the $\log$ hives to be more resistance to heat during dry spells and ants attack and that occupation rates were higher than modern hives. Beekeepers relied mainly on seasoned beekeepers for information and guidance. None of the respondents gave supplements proteins to their colonies during drought. However, some provided water and sugar solution to reduce absconding. The respondents had no information on existence of commercial supplement proteins in the market for bees. For the lack of knowledge of existence of diseases, respondents never changed brood combs. Very few mentioned they did colony division to strengthen their colonies. However, most respondents complained of absconding as a major challenge in beekeeping.

\section{Acknowledgements}

I acknowledge the Directorate of Veterinary Services for funding field data collection. My gratitude to the team who assisted in data collection and the farmers who gave us their time and access into their apiaries.

\section{References}

[1] B. Akinnuli, O. Awopetu, P. Ikubanni, and O. Agboola, "Development of Pedal Operated Honey Extractor," Br. J. Appl. Sci. Technol., vol. 16, no. 2, pp. 1-10, Jan. 2016.

[2] D. Michez, A. Nel, J.-J. Menier, and P. Rasmont, "The oldest fossil of a melittid bee (Hymenoptera: Apiformes) from the early Eocene of Oise (France)," Zool. J. Linn. Soc., vol. 150, no. 4, pp. 701-709, Aug. 2007.
[3] F. Han, A. Wallberg, and M. T. Webster, "From where did the Western honeybee (Apis mellifera) originate?," Ecol. Evol., vol. 2, no. 8, pp. 1949-1957, Aug. 2012.

[4] M. C. Arias and W. S. Sheppard, "Phylogenetic relationships of honey bees (Hymenoptera: Apinae:Apini) inferred from nuclear and mitochondrial DNA sequence data," Mol. Phylogenet. Evol., vol. 37, no. 1, pp. 25-35, Oct. 2005.

[5] O. Rueppell, C. Bachelier, M. K. Fondrk, and R. E. Page, "Regulation of life history determines lifespan of worker honey bees (Apis mellifera L.)," Exp. Gerontol., vol. 42, no. 10, pp. 1020-1032, Oct. 2007.

[6] M. I. Betti, L. M. Wahl, and M. Zamir, "Effects of Infection on Honey Bee Population Dynamics: A Model," PLoS ONE, vol. 9, no. 10, p. e110237, Oct. 2014.

[7] G. Suwannapong, M. E. Benbow, and J. C. Nieh, "Biology of Thai Honeybees: Natural History and Threats," in Bees: biology, threats and colonies, R. M. Florio, Ed. New York: Nova Science, 2012.

[8] N. Hrassnigg and K. Crailsheim, "Differences in drone and worker physiology in honeybees (Apis mellifera )," Apidologie, vol. 36, no. 2, pp. 255-277, Apr. 2005.

[9] D. Naug and B. Smith, "Experimentally induced change in infectious period affects transmission dynamics in a social group," Proc. R. Soc. B Biol. Sci., vol. 274, no. 1606, pp. 6165, Jan. 2007.

[10] T. GóMez-Moracho, P. Heeb, and M. Lihoreau, "Effects of parasites and pathogens on bee cognition: Bee parasites, pathogens and cognition," Ecol. Entomol., vol. 42, pp. 51-64, Aug. 2017.

[11] P. Neumann, J. S. Pettis, and M. O. Schäfer, "Quo vadis Aethina tumida? Biology and control of small hive beetles," Apidologie, vol. 47, no. 3, pp. 427-466, May 2016.

[12] P. Rosenkranz, P. Aumeier, and B. Ziegelmann, "Biology and control of Varroa destructor," J. Invertebr. Pathol., vol. 103, pp. S96-S119, Jan. 2010.

[13] P. Neumann and T. Blacquière, "The Darwin cure for apiculture? Natural selection and managed honeybee health," Evol. Appl., vol. 10, no. 3, pp. 226-230, Mar. 2017.

[14] M. P. Nolan and K. S. Delaplane, "Distance between honey bee Apis mellifera colonies regulates populations of Varroa destructor at a landscape scale," Apidologie, vol. 48, no. 1, pp. 8-16, Feb. 2017.

[15] E. Frey and P. Rosenkranz, "Autumn Invasion Rates of Varroa destructor (Mesostigmata: Varroidae) Into Honey Bee (Hymenoptera: Apidae) Colonies and the Resulting Increase in Mite Populations," J. Econ. Entomol., vol. 107, no. 2, pp. 508-515, Apr. 2014.

[16] T. D. Seeley and M. L. Smith, "Crowding honeybee colonies in apiaries can increase their vulnerability to the deadly ectoparasite Varroa destructor," Apidologie, vol. 46, no. 6, pp. 716-727, Nov. 2015

[17] J. C. Loftus, M. L. Smith, and T. D. Seeley, "How Honey Bee Colonies Survive in the Wild: Testing the Importance of Small Nests and Frequent Swarming," PLOS ONE, vol. 11, no. 3, p. e0150362, Mar. 2016. 
[18] B. Dainat, J. D. Evans, Y. P. Chen, L. Gauthier, and P. Neumann, "Predictive Markers of Honey Bee Colony Collapse," PLoS ONE, vol. 7, no. 2, p. e32151, Feb. 2012.

[19] G. Tantillo, M. Bottaro, A. Di Pinto, V. Martella, P. Di Pinto, and V. Terio, "Virus infections of honeybees Apis Mellifera," Ital. J. Food Saf., vol. 4, no. 3, Sep. 2015.

[20] A. G. Dolezal et al., "Honey Bee Viruses in Wild Bees: Viral Prevalence, Loads, and Experimental Inoculation," PLOS ONE, vol. 11, no. 11, p. e0166190, Nov. 2016.

[21] G. Di Pasquale et al., "Influence of Pollen Nutrition on Honey Bee Health: Do Pollen Quality and Diversity Matter?," PLoS ONE, vol. 8, no. 8, p. e72016, Aug. 2013.

[22] B. S. Tessema Zewudu and M. D. Mohammed Aman, "Beekeeping Practices, Production Potential and Challenges of Bee Keeping among Beekeepers in Haramaya District, Eastern Ethiopia," J. Vet. Sci. Technol., vol. 06, no. 05, 2015.

[23] L. A. Garibaldi et al., "From research to action: enhancing crop yield through wild pollinators," Front. Ecol. Environ., vol. 12 , no. 8, pp. 439-447, Oct. 2014.

[24] A. Al-Ghamdi and A. Nuru, "Beekeeping in the Kingdom of Saudi Arabia Opportunities and Challenges," Bee World, vol. 90, no. 3, pp. 54-57, Jan. 2013.

[25] A. Alqarni, M. Hannan, A. Owayss, and M. Engel, "The indigenous honey bees of Saudi Arabia (Hymenoptera, Apidae, Apis mellifera jemenitica Ruttner): Their natural history and role in beekeeping," ZooKeys, vol. 134, pp. 83-98, Oct. 2011.

[26] F. Mutinelli, "The spread of pathogens through trade in honey bees and their products (including queen bees and semen): overview and recent developments," Rev. Sci. Tech. Int. Off. Epizoot., vol. 30, no. 1, pp. 257-271, Apr. 2011.

[27] R. E. Mallinger, H. R. Gaines-Day, and C. Gratton, "Do managed bees have negative effects on wild bees?: A systematic review of the literature," PLOS ONE, vol. 12, no. 12, p. e0189268, Dec. 2017

[28] P. Graystock, E. J. Blane, Q. S. McFrederick, D. Goulson, and W. O. H. Hughes, "Do managed bees drive parasite spread and emergence in wild bees?," Int. J. Parasitol. Parasites Wildl., vol. 5, no. 1, pp. 64-75, Apr. 2016.

[29] D. vanEngelsdorp and M. D. Meixner, "A historical review of managed honey bee populations in Europe and the United States and the factors that may affect them," $J$. Invertebr. Pathol., vol. 103, pp. S80-S95, Jan. 2010.

[30] P. Neumann and N. L. Carreck, "Honey bee colony losses," $J$. Apic. Res., vol. 49, no. 1, pp. 1-6, Jan. 2010.

[31] W. Glenny, I. Cavigli, K. F. Daughenbaugh, R. Radford, S. E. Kegley, and M. L. Flenniken, "Honey bee (Apis mellifera) colony health and pathogen composition in migratory beekeeping operations involved in California almond pollination," PLOS ONE, vol. 12, no. 8, p. e0182814, Aug. 2017.

[32] H. F. Boncristiani et al., "In Vitro Infection of Pupae with Israeli Acute Paralysis Virus Suggests Disturbance of Transcriptional Homeostasis in Honey Bees (Apis mellifera)," PLoS ONE, vol. 8, no. 9, p. e73429, Sep. 2013.

[33] O. Boecking and E. Genersch, "Varroosis - the Ongoing
Crisis in Bee Keeping," J. Für Verbraucherschutz Leb., vol. 3, no. 2, pp. 221-228, May 2008.

[34] N. Al-Waili, K. Salom, A. Al-Ghamdi, and M. J. Ansari, "Antibiotic, Pesticide, and Microbial Contaminants of Honey: Human Health Hazards," Sci. World J., vol. 2012, pp. 1-9, 2012.

[35] H. D. Affognon et al., "Adoption of modern beekeeping and its impact on honey production in the former Mwingi District of Kenya: assessment using theory-based impact evaluation approach," Int. J. Trop. Insect Sci., vol. 35, no. 02, pp. 96102, Jun. 2015.

[36] T. Carroll and J. Kinsella, "Livelihood improvement and smallholder beekeeping in Kenya: the unrealised potential," Dev. Pract., vol. 23, no. 3, pp. 332-345, May 2013.

[37] G. R. Williams et al., "Colony Collapse Disorder in context," BioEssays, vol. 32, no. 10, pp. 845-846, Oct. 2010.

[38] R. Subramanian, H. Umesh Hebbar, and N. K. Rastogi, "Processing of Honey: A Review," Int. J. Food Prop., vol. 10, no. 1, pp. 127-143, Jan. 2007.

[39] A. Sircar and K. Yadav, "Application of Geothermal Water for Honey Processing," in 43rd Workshop on Geothermal Reservoir Engineering, Stanford University, Stanford, California, 2018.

[40] A. K. Breslin, B. M. Meyer, W. S. Dria, D. F. Vanata, and A. V. Greene, "Enumeration and Identification of Bacterial Contaminants in Commercial and Locally Produced Honey," BIOS, vol. 82, no. 4, pp. 103-111, Dec. 2011.

[41] S. F. Pernal, and Melathopolos, "Monitoring for American foulbrood spores from Honey and Bee samples in Canada," APIACTA, vol. 41, 2006.

[42] O. I. Awino, R. Skilton, S. Muya, S. Kabochi, H. Kutima, and M. Kasina, "Varroa mites, viruses and bacteria incidences in Kenyan domesticated honeybee colonies," East Afr. Agric. For. J., vol. 82, no. 1, pp. 23-35, Jan. 2017.

[43] M. Fazier et al., "A scientific note on Varroa destructor found in East Africa; threat or opportunity?," Apidologie, vol. 41, no. 4, pp. 463-465, Jul. 2010.

[44] E. Muli et al., "Evaluation of the Distribution and Impacts of Parasites, Pathogens, and Pesticides on Honey Bee (Apis mellifera) Populations in East Africa," PLoS ONE, vol. 9, no. 4, p. e94459, Apr. 2014

[45] Spivak, Marla and Gary S. Reuter, Honey Bee Diseases and Pests. 2016.

[46] N. Forfert, M. E. Natsopoulou, E. Frey, P. Rosenkranz, R. J. Paxton, and R. F. A. Moritz, "Parasites and Pathogens of the Honeybee (Apis mellifera) and Their Influence on InterColonial Transmission," PLOS ONE, vol. 10, no. 10, p. e0140337, Oct. 2015.

[47] J. S. Pettis, D. vanEngelsdorp, J. Johnson, and G. Dively, "Pesticide exposure in honey bees results in increased levels of the gut pathogen Nosema," Naturwissenschaften, vol. 99, no. 2, pp. 153-158, Feb. 2012.

[48] C. Vidau et al., "Exposure to Sublethal Doses of Fipronil and Thiacloprid Highly Increases Mortality of Honeybees Previously Infected by Nosema ceranae," PLOS ONE, vol. 6, no. 6 , p. e21550, Jun. 2011. 
[49] C. W. W. Pirk, U. Strauss, A. A. Yusuf, F. Démares, and H. Human, "Honeybee health in Africa-a review," Apidologie, vol. 47, no. 3, pp. 276-300, May 2016.

[50] A. Jacques et al., "A pan-European epidemiological study reveals honey bee colony survival depends on beekeeper education and disease control," PLOS ONE, vol. 12, no. 3, p. e0172591, Mar. 2017.
[51] G. Formato and F. J. M. Smulders, "Risk management in primary apicultural production. Part 1: bee health and disease prevention and associated best practices," Vet. Q., vol. 31, no. 1, pp. 29-47, Mar. 2011.

[52] ANSES Opinion, "Co-exposure of bees to stress factors," French agency for food, environmental and occupational health and safety, Expert Report Request No 2012-SA-0176, 2015. 